in more advanced subjects be included in the undergraduate curriculum ?'

Profrsson F. Morley : 'Certain phases of the general question.'

Professor J. W. A. Young: 'Collegiate preparation for the teaching of mathematics in secondary schools.'

A general discussion of the subject then took place.

On each evening of the meeting, the members generally took advantage of the opportunity to dine together.

The next regular meeting of the Society will be held in New York on Saturday, October 27th.

F. N. Cole, Secretary.

\section{THE RELATION OF BIOLOGY TO PHYSI-} $O G R A P H Y$.

THE studies of paleontologists have been among our chief sources of information concerning the physiography of various regions in past geologic periods. Far-reaching conclusions have been drawn from faunal resemblances and differences as to the relations of sea and land, the presence or absence of barriers and the direction of marine currents during particular epochs of the earth's history. It is evident that biology should bear a relation to physiography analogous to that which paleontology bears to paleophysiography. Some of the ways in which the two distinct sciences react upon each other have been pointed out by Woodworth,* and it is the purpose of the writers to call attention to a specific case in point where identical conclusions were reached quite independently by different investigators pursuing distinct lines of research.

These results are of the utmost importance in the particular problems upon which they bear, but their chief value at the present time lies in the fact that they bring physiography and biology upon common

* J. B. Woodworth, 'The Relation Between Baseleveling and Organic Evolution,' Am. Geol., Vol. XIV., pp. 209-235, 1894. ground and show that each may and should receive assistance from the other.

In discussing the origin and recent history of the physical features of the southern Appalachians* in 1894 the writers advocated the theory that the upper Tennessee River formerly flowed into the Gulf of Mexico by way of the present Coosa and Alabama rivers, and that it was diverted to its present course through the Cumberland Plateau in the latter part of Tertiary $\{$ Neocene (?) $\}$ time. The former course of this river is shown on the accompanying outline map by the dotted line $A$ which extends in the direction of the upper Tennessee from the vicinity of Chattanooga southwestward to the Coosa in eastern Alabama.

This theory was again advocated by the senior author $\dagger$ in 1897-98, and the evidence in its support was presented in somewhat greater detail. The conclusions in both reports were based entirely upon physiographic evidence-such as the character of the Tennessee-Coosa divide, the newness of the gorge below Chattanooga and the general arrangement of the drainage lines.

We recently learned with considerable surprise and gratification that Mr. Charles T. Simpson, of the Smithsonian Institution, had independently reached the same conclusion from a study of the fresh water mollusca contained in the rivers in question.

In an equally unexpected manner Mr. Simpson has corroborated the conclusions of the junior author + regarding the changes which have taken place in the head branches of the Coosa, Chattahoochee, and Savannah rivers.

The conclusion that the Etowah River had been robbed by the Chattahoochee

* Geomorphology of the Southern Appalachians : Nat. Geog. Mag., Vol. VI., pp. 63-126, May, 23, 1894.

† Physiography of the Chattanooga District. 19th Ann. Rept., U. S. Geol. Survey, Part II., pp. 1-58.

$\ddagger$ Drainage Modifications and their Interpretation. Jour. Geol., Vol. 4, pp. 567-581 and 657-673. 
River was based upon the following facts : (1) the lowness of the divide at Dahlonega, Georgia between the Etowah River and a branch of the Chattahoochee River; (2) the similarity of the alignment of the be- change was supposed to have taken place when the surface relief was slight, presumably on the elevation of the Tertiary peneplain above baselevel.

The conclusion that the upper course of

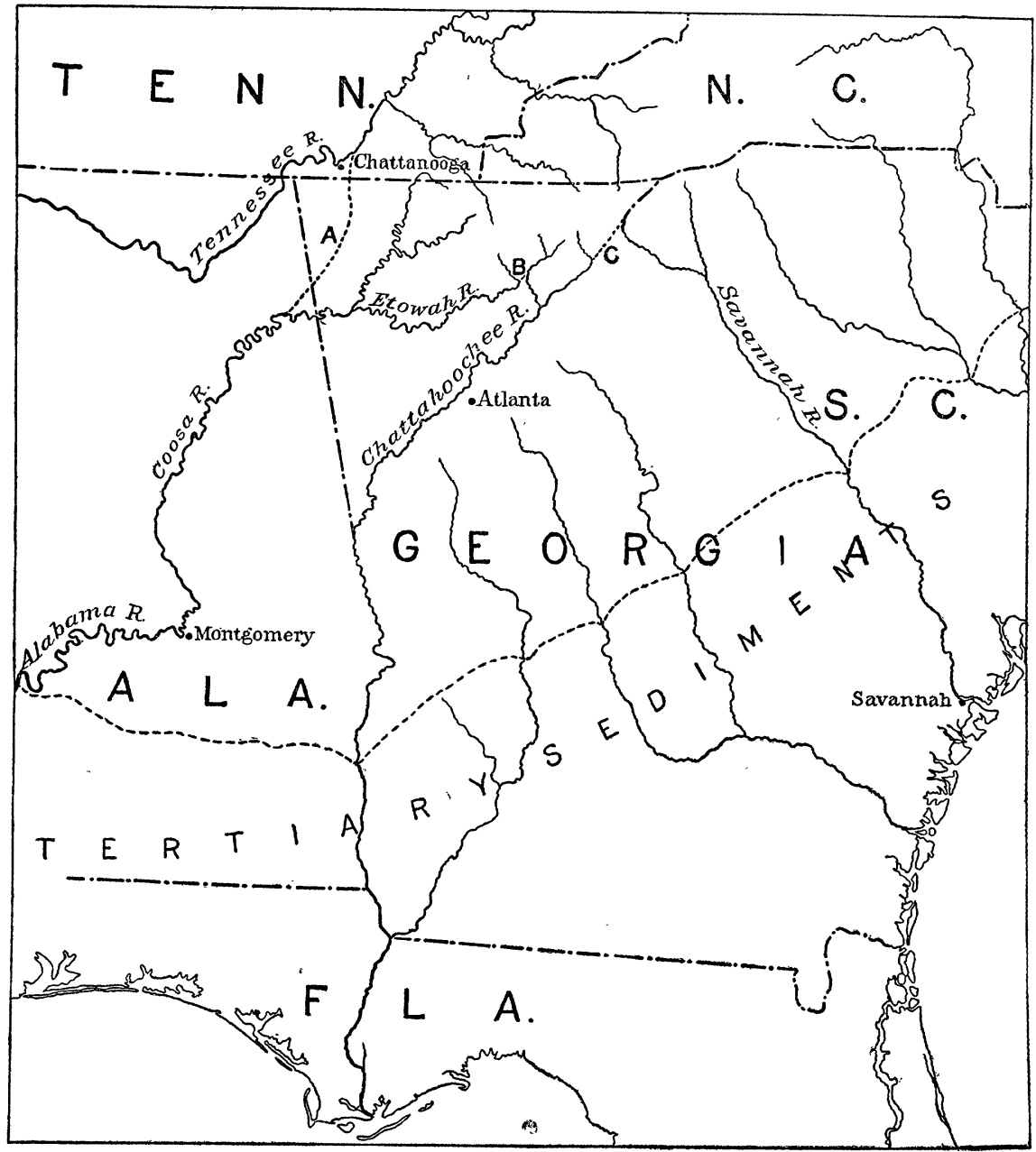

Fig. 1. Drainage map of the Southern Appalachian region, showing recent stream diversions. Hayes and Campbell.

headed portion with that of the remaining Etowah River, as shown at $B$ on the map and (3) the plainly apparent tendency of the southeastward flowing streams to encroach upon their neighbors on the northwest in all the territory about the headwaters of the three rivers in question. This the Chattahoochee River has been transferred to the Savannah system by diversion near Tallulah Falls, at the point marked $C$ on the map, was based on similar grounds, but in this case the proof is stronger for the southeastward flowing streams show even a greater tendency to encroach toward the 
northwest than they do in the vicinity of Dahlonega.

Thus the purely physiographic evidence shows that there was a former connection between the upper Tennessee River and the Coosa system by which the molluscan fauna could easily pass from one to the other. It also shows conclusively that a part of the Etowah River has been transferred bodily to the Chattahoochee system. Such a wholesale shifting of divides would result in the transference of such of the Coosa-Tennessee forms as then existed in the headwaters of the Etowah River.

This infusion of new forms spread throughout the Chattahoochee system, even to its headwaters, but the foreign types presumably constituted only a small proportion of the existing fauna. When the Savannah River cut through the divide and captured the upper part of the basin of the Chattahoochee, it carried with it a limited number of forms belonging to the Coosa-Tennessee type. Thus in each successive transfer the percentage of the original forms has grown less and less, until in the Savannah River, as reported by Mr. Simpson, they are scarcely recognizable.

Beyond Savannah, toward the northeast, none of the peculiar Tennessee forms have been found, nor is there any indication in the surface configuration of there having been any drainage changes of consequence in this region.

In most respects the biological evidence simply corroborates the conclusions based upon a study of the surface features, but in the question of age relations it throws some new light upon the problem. The migration of Coosa-Tennessee fauna from west to east shows conclusively that the changes in drainage must have followed a similar order, hence the diversion at Dahlonega must have preceded that which occurred near Tallulah Falls. This important fact presumably could never have been deter- mined from the physiographic evidence alone.

Throughout the whole region there is a surprisingly close agreement between the biologic and the physiographic evidence which clearly indicates that biology should stand in the same relation to physiography that paleontology does to paleo-physiography.

The following brief statement of the evidence on which Mr. Simpson bases his conclusions was prepared at our suggestion for publication in advance of the more detailed report which the author has in preparation.

C. W. HAYES,

M. R. CAMpbell.

U. S. Geological Survey.

ON THE EVIDENCE OF THE UNIONID $A$ REGARDING THE FORMER COURSES OF

THE TENNESSEE AND OTHER SOUTHERN RIVERS.

Several years ago while studying the life history and distribution of the Unionidæ, or Pearly Fresh Water mussels I was struck by the close relationship existing between that part of the mollusk fauna of the Tennessee River drainage system and that of the Alabama.

Within the Mississippi drainage basin there is found the richest and most wonderful, as well as the most highly developed Unione fauna of any part of the world. Perhaps not less than 400 species, ât a most conservative estimate, are found in this area. The Unione fauna of the Tennessee drainage system (including that of the Cumberland) contains a very large proportion of the species found throughout the Mississippi area, and in addition to these a great many peculiar species found nowhere else in the Mississippi system. The genus Pleurobema, as I have defined it, a large group of forms having rather heavy, triangular shells, generally tawny colored, with broken, green rays, has its metropolis in the Tennessee 